\title{
Politeness-induced semantic change: The case of quand même
}

\author{
K A T E B EECHING \\ University of the West of England, Bristol
}

\section{A B S T R A C T}

This article contributes to a growing body of theory that posits language-external, social factors as a primary motor in diachronic change. Politeness theory and the use of variationist approaches enable us to posit, and test, the hypothesis of a type of pragmaticalization, which I call Politeness-Induced Semantic Change (PISC). Historical data on quand même are presented that give tentative credence to such a model. Moeschler and de Spengler's (1981) and Waltereit's (2001) speechact theoretic analyses of quand même are reinterpreted within the framework of politeness theory and sociopragmatics. The ensuing corpus investigation of the grammaticalization and pragmatico-semantic evolution of quand même from 1500-2000 highlights the fact that not only the innovation but also the propagation of a new form-function configuration depend on social factors; politeness theory may have explanatory power in capturing the ever-changing social patterning of linguistic features and the conditions that favor the spread of innovation.

The approach to language change taken in this article is broadly sympathetic to that outlined by Croft (2000) in two fundamental ways. First, it concurs with his insistence (2000:4) that "the real entities of language are utterances and speakers' grammars. Language change occurs via replication of these entities not through inherent change of an abstract system." Second, it adopts his distinction between innovation - the mechanisms that involve both structure and function-and propagation- "the mechanisms for which are essentially social namely the various factors discussed by sociolinguists." ${ }^{1}$ This study of quand même illustrates these two phases, first by exploring the shift in the formfunction relationship, and second in taking a quantitative sociolinguistic approach (see Milroy, 1992:230) to the variable distributional frequency of its usages in a representative sample of the community of French speakers in hexagonal France.

I wish to acknowledge the very helpful and detailed comments of Maj-Britt Mosegaard Hansen and anonymous reviewers from Language Variation and Change on a draft version of this article. Remaining inadequacies are, of course, entirely my own. I also recognize a debt of gratitude to the Research Committee of the Faculty of Humanities, Languages and Social Sciences of the University of the West of England, Bristol, who granted me the research leave required to complete the article. 
POLITENESS THEORY

The scope of this article does not permit lengthy evaluation of politeness theory. Many theorists (e.g., Kasper, 1990, cited in Eelen, 2001:21) distinguished between two main trends in its conceptualization: conflict avoidance and social indexation. It is this dual conceptualization that underlies the two faces of what I call Politeness-Induced Semantic Change (PISC) and which manifest themselves, respectively, in innovation and propagation. Considerations to do with politeness (conflict avoidance) promote new form-function configurations; the spread of these is dependent on social evaluation (deriving from social indexation). SpencerOatey (2000) reviewed Brown and Levinson's (1987 [1978]) theory in the context of rapport-management, and my contention falls in with her line of argument. Certain linguistic functions lend themselves particularly well to the projection of humility, which is a key element in face-to-face interaction. The exponents of these "humility-projecting" functions include vague words, attenuators, downtoners, and mitigators, expressions of uncertainty and tentativeness and of belief. The necessity to include hedging expressions in every face-to-face encounter leads to their abundance in speech and to the pragmaticalization of forms with particular semantic cores. Though Brown and Levinson (1987) did not specifically address the question of language change, they expressed the view (1987:255) that "face redress is a powerful functional pressure on any linguistic system." An increase in frequency in a new politeness-mediating form-function configuration may lead to a shift in the core meaning of an item in the manner described by Traugott and Dasher (2002). The politeness-induced invited inference spreads throughout the population depending on factors having to do with social indexation and completes the PISC.

Out of an explicit logical adversative or concessive sense (QM1), quand même has developed a new attenuating politeness-marking sense (QM2). For some speakers, QM2 is, for this reason, salient (see Kerswill \& Williams, 2002) and may be hypercorrectly avoided. QM (1 and 2) are relatively frequent and thus good contenders for salience.

QUAND MÊME: FROM CONCES SIVE CONJUNCTION TO HEDGING PARTICLE

Quand même appears to have developed in the first instance as a strengthened form of one of the senses of quand - an oppositional or concessive rather than a temporal sense. The semantic shifts from (i) a temporal to a concessive sense and (ii) a strengthened or emphatic form to a normalized or routinized one are widely attested in both English and French. Traugott (1982:254) demonstrated the manner in which the noun while meaning "period, time" (cf., G. Weile) "came from its nominal and adverbial uses to be a temporal connective.... only in the eighteenth century did while come to indicate [a] concessive relation."

That quand should extend its scope to include not just a temporal but also a concessive sense is thus a process that is far from being unprecedented. Quand 
même appears to have followed processes of grammaticalization similar to the negative particle ne ... pas (see Posner, 1997:370-374), involving loss of the emphatic force of the reinforcer. Though it is still written as two words, the expression quand même, originally a fusion of a temporal conjunction with a reinforcer, gradually underwent a semantic sea-change as it grammaticalized, coalesced as an inseparable unit, and moved from a conjunction to an adverbial usage.

Moeschler and de Spengler (1981) described quand même as having a logical, concessive value based on a causality relation, which may be expressed as $p$ mais quand même $q$ ( $\mathrm{p}$ but all the same $\mathrm{q}$ ), giving the example:

La rivière était en crue mais le pont ne s'est pas quand même écroulé.

The river was in spate but all the same the bridge did not collapse.

Our real-world expectations that the swollen river might cause the bridge to crumble are refuted in $q$. Moeschler and de Spengler (1981:10) recognized in a footnote that mais (but) is perhaps the concessive marker in their examples and that it may be the case that "notre description a été malencontreusement influencée par la présence de mais dans les exemples étudiés" ("our description has been affected by the inopportune presence of but in the examples studied").

In the example:

A: Manhattan est un film superbe.

B: Il est quand même trop long

A: Manhattan is a great film.

B It's too long though.

Moeschler and de Spengler argued that the first movement of the concession is missing and quand même is refutative. This could equally have appeared more fully, as follows:

A: Manhattan est un film superbe.

B: Certes,

En effet, mais il est quand même trop long.

Oui,

A: Manhattan is a great film.

B: Indeed,

You're right, [lit.] but it's too long, though.

but it's a bit too long.

Yes,

Moeschler and de Spengler did not directly address the question of the redundancy of quand même in such an utterance which comes out particularly clearly 
in the English translation. The literal translation "but it's too long, though" is more naturally rendered "but it's a bit too long." The adversative quality is, after all, expressed in mais (but). My own interpretation is that quand même softens the refutation and functions thus as a hedging particle, protecting the faces of both the refuted and the refuter.

As Moeschler and de Spengler suggested (1981:195), "Il est quand même trop long" ("It's too long, though") contains an implicit rejection of the proposition "Manhattan est un film superbe" ("Manhattan is a great film") of the type "Non, il n'est pas superbe car il est trop long" ("No, it's not great because it's too long”). Quand même allows a speaker "à refuser le contenu préalablement asserté par l'interlocuteur, c'est-à-dire à réaliser un acte de réfutation mais sur le mode de l'implicitation et de l'atténuation" ("to reject the proposition previously asserted by the interlocutor, that is to say, to perform an act of refutation but in an implicit and attuned manner"). Moeschler and de Spengler argued that quand même mediates the idea of a norm, and this is a social rather than a logical norm. They cited the example of J.M. arriving unexpectedly at N.S.'s house with five friends. N.S. exclaims: "C'est quand même exagéré!" (lit.: "That's going too far all the same!" = "That's going a bit too far!") This is explained as "Je dis quand même que c'est exagéré (bien qu'en tant que maîtresse de maison, je ne devrais pas manifester une désapprobation)" ("I say all the same that it's going too far (even though as mistress of the house I should not show my disapproval"). An interpretation that draws on politeness theory supports the argument that the presence of quand même attenuates what would otherwise be an over-strong assertion. The faces of both the speaker and the hearers are thus saved. The sequence of events is as follows:

1. J.M. commits an FTA (Face-Threatening Act) by arriving unexpectedly with five friends;

2. N.S. must execute face-work by registering that an FTA has occurred;

3. She must attenuate the expression of her disapproval so as to save her own face (self-image as the ever-welcoming hostess) and J.M.'s face (accusing him of antisocial behavior) and the faces of the other guests (who are numerous, unexpected and could feel unwelcome).

(Once again, the most natural English translation, "That's going a bit too far" draws out the underlying attenuating force of quand même in this example).

Moeschler and de Spengler suggested that a concessive usage of quand même is more often associated with monologue and a refutative usage with dialogue, but that the essential pragmatic effect of quand même is to refer to a norm and "de créer une rupture entre le monde décrit et le monde normé." In the examples in corpora of naturally occurring speech — and in both the Bristol and the Orléans Corpus this is more often monologal than dialogal in style ${ }^{2}$ - quand même is far more often an attenuator than a logical concessive device, whether or not the information is implicit or explicit.

In contemporary French, there are two main uses of quand même. In the first, it retains an adversative sense; in the second it has a less adversative or relational 
function that appears to hint at a possible over-assertiveness. This latter sense is sensitively brought out by Grieve (1996), whose words seem to capture the manner in which quand même can serve face needs in preempting an anticipated objection or criticism on the part of the interlocutor.

This mode has a familiar tone, more spoken than the first. Robert's definition is $I l$ faut avouer, à vrai dire, on en conviendra. To that list, one should probably add je ne devrais pas le dire mais ... In speech it is a tactical gambit which, by sketching an apparent attenuation of what might be sensed as the impropriety of an affirmation, can enable the reinforcement of the latter. It facilitates what has been called la mise en acceptabilité d'une contradiction (Moeschler \& Spengler, 1981, 110). That is, it offers a justification for the statement it accompanies, even a sort of excuse or apology for it. But thereby it too has an adversative quality, faint and implicit, in that it hints at contradicting an assumed objection. (Grieve, 1996:417, my emphasis).

In his speech-act-theoretic analysis of quand même, Waltereit (2001:1400-1405) took a similar stance and demonstrated how "it exploits in a very particular fashion the rhetoric of counter-expectation." In my view, however, Waltereit's analysis remains too closely wedded to the propositional and the introduction of Grieve's notion of "excuse" or "apology" allied to face needs and considerations of politeness can help in explaining its usefulness when applied to the two types of speech acts to which Waltereit claims quand même is tied: subjective evaluations and directives. Referring to Searle, Waltereit claims that directives require that it is not obvious to both $\mathrm{S}$ (speaker) and $\mathrm{H}$ (addressee) that $\mathrm{H}$ will do A (act) in the normal course of events "of his own accord" and goes on to say that "the modal particle seems to work as a (negative) politeness device" (Waltereit, 2001:1403). It is my contention that the very usefulness, ubiquity, and frequency of quand même as a politeness device may be gradually eclipsing its propositional, adversative qualities. The focus of Waltereit's (2001) article is on expressions which set up "preparatory conditions" to accommodate the speech act at minimal expense. He posits that such forms arise through metonymic semantic change and that the relevant metonymy takes as its conceptual base a contiguity between a sound chain and a speech situation. My only adjustment of this is to underline that at the extreme pragmatic end of the spectrum, the conceptual base is semantically bleached, the term functioning in the speech situation entirely as a politenessmediating hedging particle.

\section{METHO D O O G Y}

\section{The corpora investigated}

The study includes a survey of the evolution of quand même historically from the 16th to the 20th century, using the corpus of literary texts contained in FRAN$\mathrm{TEXT}^{3}$ along with a comparison of the functions of quand même in two spoken corpora: the 1968 Orléans Corpus ${ }^{4}$ and the 1988 Bristol Corpus. ${ }^{5}$ 
As we have no recordings of spontaneous spoken French before the advent of the tape-recorder in the 20th century, to gauge how the form evolved over the centuries we must look to written records. FRANTEXT contains 210 million words in 3737 texts from the 16th to the 20th century and thus represents a formidable source of robust evidence. What is more, it is consultable by subscription on-line and gives information about dates and numbers of texts, word counts and so on. Examples can be brought up on screen, with greater context, if this is required, so that colligations and collocations may be examined.

The Orléans Corpus is made up of transcriptions of sociolinguistic interviews recorded in Orléans between 1968 and 1971. The subsection we are looking at comprises 157 hour-long face-to-face interviews on standardized questionnaires with a statistically random sample chosen according to the 1968 Institut national de la statistique et des études économiques (INSEE) census list. The aim, according to the authors in their catalogue, was to constitute a sociolinguistically representative sample of the population in 1968. The speakers have been attributed an INSEE coding and have been classified according to sociocultural categories established by Alix Mullineaux (AM). There is no further information about the manner in which Alix Mullineaux allocated subjects to sociocultural groups.

The Bristol Corpus, on the other hand, is made up of transcriptions of some of the interviews recorded by myself over the years 1988-1991. These interviews were recorded and some were transcribed as the basis for French textbooks for A-level and undergraduate students of French published by Cambridge University Press and Oxford University Press between 1990 and 1993 (Beeching \& Le Guilloux, 1990, 1993). The aim of these recordings collected in the Minervois, the Lot, Brittany, and Paris was to obtain a representative sample of French speakers from different social and regional backgrounds speaking spontaneously about their jobs and on a range of social issues, such as tourism and the tourist attractions of a particular region, the environment, the place of the Breton language and culture, religion, fashion and clothing, architecture, cinema and theatre, politics, setting up a business, the computerization of society, and so on. The interviewer's aim was to stimulate lively and naturalistic spontaneous speech in the type of interview that Wolfson (1997:120) called "the so-called spontaneous interview" and which she claimed has been said to provide excellent material. The Bristol Corpus is made up of a subset of these interviews that was selected as the basis for my $\mathrm{PhD}$ thesis (an abridged version of which was published in 2002). In the thesis I focused on gender and social class and the Bristol Corpus aimed to contain balanced samples of speech from men and women according to three educational backgrounds: those who left school without the baccalauréat, those who gained the baccalauréat, and those who gained in addition a university degree or degrees. Although the recordings were not made with a sociolinguistic research project in mind, the notion that students of French should be exposed to samples of authentic spontaneous speech and to a degree of variation dictated a strong sociolinguistic bias that recommends the use of the corpus in studies of variation. It distinguishes itself from other corpora in having a good representation of workingclass speech-many researchers use speakers close to hand in universities, thus excluding a range of speakers of this type. Though the Bristol Corpus cannot 
claim that the content is constant for each speaker and, in this way, differs from the Orléans Corpus, it would not exist had it not been for the patronage of the University Presses of Oxford and Cambridge who commissioned the textbooks, for which thematic uniformity across interviews would have been inappropriate. One is struck, moreover, by the similarity in style of the interviews in the two corpora. The interviewer in both cases is a teacher of French in Britain, the interviews are between two participants with little overlapping between turns and the interviewees are aware that they are responding as typical French people representing their country, as well as their own individual views, for British learners of French. From the Orléans Corpus, 24 speakers were selected, 4 males and 4 females, with 8 speakers from each of the educational backgrounds under consideration (amounting to 287,272 words). Of the 95 speakers in the Bristol Corpus, only those were selected who used quand même at least once. A number of the interviews in the Bristol Corpus are very short and, for this reason, did not include occurrences of quand même. The subjects of the 55 interviews retained were balanced according to sex and educational background, so that the word count for each cell was approximately the same. The total word count was 132,933. The word count of all the spoken material was thus 420,205 , almost half a million words of transcribed speech.

The comparability of the corpora might be said to be imperfect-a perennial problem - and the difficulties are compounded when discourse features are the object of study. As Macaulay (2002a:298) pointed out, the study of discourse variation is still at an elementary stage and there are many variables that affect samples of speech. He claimed, however, "Yet we need not despair. One way forward is in replication. As more studies are carried out, the influence of accidental factors may be easier to detect." 6

I chart here the results of my investigation of the two spoken corpora at my disposal, one from 1968, the other from 1988, in the hope that this will permit later researchers to replicate the studies with larger corpora and arrive at finer distinctions and firmer conclusions. Any conclusions drawn here can only be tentative. Differences between the spoken corpora may be a result of diatopic as opposed to diachronic factors and/or may reflect differences in the manner in which the data were collected.

\section{Rates of occurrence}

First, rates of occurrence of conjunctival and adverbial quand même were charted in FRANTEXT. Second, usages of quand même were surveyed in the Orléans (1968-1971) Corpus and the Bristol (1988-1991) Corpus. As the conjunctival usage does not appear in the more recent spoken corpora, only the adverbial usages (adversative and relational) of quand même were charted with subdivisions according to both the educational background and the sex of the speakers. It was hypothesized that there might be some evidence of a shift towards a more relational usage in the later corpora and, in the case of the spoken corpora, that there might be some indications concerning class and sex as to where such a shift might be generalizing more rapidly. 
In my exploration of the degree of pragmaticalization of quand même and (in the case of the two corpora of spoken French) its sociolinguistic stratification, my first job, having selected representative samples from the corpora, was to categorize individual occurrences of the particle as "adversative" or "relational." As polysemy and multifunctionality are the unmarked case, criteria had to be established to assist me in conducting this process in as objective and rigorous a manner as possible.

\section{Quand même: criteria for subclassification}

The criteria ${ }^{7}$ used to classify occurrences of quand même as either an explicit adversative or an implicit (or relational) one were as follows.

Explicit adversative. Explicit adversative uses of quand même have two conjoined clauses in which there is an explicitly expressed adversative opposition of the type (Not) $\mathrm{P}$, (but) quand même $\mathrm{Q}$.

Example:

Ce n'est pas une ville qui bouge, c'est une ville qui a quand même un cinéma la saison estivale pendant la saison estivale et deux boites de nuit, deux discothèques.

(Bristol Corpus, Interview 4, lines 35-36)

The interviewer had posed the question: "What is there for young people in Sarzeau?" The "bridging" implicatures in "Ce n'est pas une ville qui bouge" (It's not a very lively town) include, in the context of the interviewer's question, the absence of nightlife, such as cinemas and clubs, a situation that is refuted in $\mathrm{Q}$ with a reinforcing quand même. If quand même had been omitted, the discourse structure of the sentence would have been P, Q (exemplification), which would constitute a contradiction and not make sense. There is, however, in addition to the oppositional sense, a slightly apologetic tone to quand même- the town may not be very lively, but it does at least have a cinema and two night clubs. So, although we can categorize quand même here as an explicit adversative according to our established criterion, it also contains the germ of implicit or relational quand même. It is this invited inference that coexists with the explicit adversative sense that is generalizing to become one of the core or coded meanings of quand même.

Implicit adversative/relational. The logical two-part structure (Not) P (but) quand même $\mathrm{Q}$ is absent. It may be possible to infer/invent an oppositional sense, but in many cases this appears speculative and hardly justified by the contextual implicatures.

Example:

Ça a l'air d'être une famille quand même assez riche.

(Bristol Corpus, Interview 1, line 647)

Two adolescent boys were shown magazine pictures of men in different roles and contexts to elicit from them what they felt was the proper role of men and 
women in society and the effect that the roles portrayed in advertising might have. The picture discussed here was an advertisement for Sopiquet tuna and showed a mother arriving at the dinner table with a steaming bowl of food, the father and children sitting expectantly at table. It is nearly impossible to infer or even invent a "Q" oppositional, although we can infer a type of hedge that could be glossed along the lines of: "Well, it looks like quite a rich kind of family" (with an implied inference that this scenario would not be typical of all families in France, but only of the rich ones). There is a hedging (and simultaneously boosting) quality in all cases categorized as implicit adversatives/ relationals-a sense that remarks are restricted in scope, and the speaker wishes the strength of their assertion to be attenuated. It allows speakers to protect their own and their interlocutors' face. [See Beeching, 2002:20-23 for a fuller discussion of the contribution of Kerbrat-Orecchioni (1997), and the notion of the face-enhancing act, to Brown \& Levinson's (1987) politeness theory.] The processes of polysemy and the very gradual emergence of a new sense, coexisting with the traditional usage, are at the very heart of semantic/pragmatic change, which can be charted in the probabilistic terms reflected in distributional frequencies. Polysemy and vague meanings constitute a problem for researchers attempting to pin down the gradually developing independence of a new core sense but, along with sociolinguistic variation, they are fundamental to PISC. Polysemy and indeterminacy of meaning constitute the raw material essential to semantic/pragmatic change.

\section{Summary}

The difficulties of allocating each example of quand même to a functional subcategory, with 639 examples studied in detail from the "Théâtre" section of the FRANTEXT Corpus, 477 in the selected interviews from the Orléans Corpus, and 214 in the Bristol Corpus should not be underestimated. In a practical workshop designed to test the reliability of my interpretation of quand même in context and conducted with eight native-speaking French linguists working with MarieAnnick Morel at the Université de Paris III, it was possible to reach consensus, but only through strict adherence to the criteria formulated here. I have attempted to be as objective as possible in allocating examples to only two categoriesexplicit (adversative) and implicit (relational) usages of the particle. To fall into the first category, P had to appear explicitly in the speaker's utterance.

RES U L T S

Survey of rates of occurrence of quand même in FRANTEXT

Table 1 charts the number of occurrences of quand mesme/quand même that appears as a colligated expression in all of the texts in FRANTEXT, across the centuries. There is a gradual but regular increase in numbers of occurrence of quand même overall and, as we can see in Table 2, this was particularly marked in the last 50 years of the 20th century. 
TABLE 1. Rates of occurrence of quand même per 10,000 words in FRANTEXT, across the centuries

\begin{tabular}{|c|c|c|c|c|c|}
\hline Period & $\begin{array}{l}\text { Number } \\
\text { of Texts }\end{array}$ & Word Count & $\begin{array}{l}\text { Occurrences of } \\
\text { quand mesme }\end{array}$ & $\begin{array}{l}\text { Occurrences of } \\
\text { quand même }\end{array}$ & $\begin{array}{c}\text { Rate of } \\
\text { Occurrence of } \\
\text { quand même } \\
\text { per } 10,000 \text { words }\end{array}$ \\
\hline $1500-1599$ & 138 & $4,931,242$ & 11 & 0 & 0.022 \\
\hline $1600-1699$ & 570 & $21,804,117$ & 197 & 167 & 0.166 \\
\hline $1700-1799$ & 560 & $34,952,313$ & 9 & 540 & 0.157 \\
\hline $1800-1899$ & 935 & $67,543,742$ & 0 & 1477 & 0.218 \\
\hline $1900-2000$ & 1534 & $88,303,281$ & 0 & 4971 & 0.562 \\
\hline
\end{tabular}

TABLE 2. Rates of occurrence of quand même per 10,000 words in FRANTEXT in the 20th century

\begin{tabular}{lcccc}
\hline \hline Period & $\begin{array}{c}\text { Number } \\
\text { of Texts }\end{array}$ & Word Count & $\begin{array}{c}\text { Occurrences } \\
\text { of quand } \\
\text { même }\end{array}$ & $\begin{array}{c}\text { Rate of } \\
\text { Occurrence of } \\
\text { quand même } \\
\text { per 10,000 words }\end{array}$ \\
\hline $1900-1949$ & 899 & $49,632,043$ & 2335 & 0.47 \\
$1950-2000$ & 635 & $38,671,238$ & 2636 & 0.68 \\
\hline \hline
\end{tabular}

Table 3 charts rates of quand mesme/quand même in different genres of writing - the most formal written modes, such as the funerary orations in the genre "Eloquence" have low rates of occurrence, whereas those which assimilate more to informal everyday speech, such as plays, correspondence, and novels have higher rates of occurrence. Some caution is required in interpreting such data, as the 19th and 20th centuries are marked by the development of the novel. FRANTEXT reflects this in the number of such texts included in the corpus for the 19th and 20th centuries, and this is, in turn, reflected in the rates of occurrence of quand même for those centuries. However, to the extent that FRANTEXT is intended as representative of the texts written and the type of language used, we can consider the rates of occurrence of quand même as being representative of the period indicated.

Although novels and correspondence have the highest rates of occurrence of quand même, it was decided in the first instance to survey uses of quand même in theatre, first because, though it has been said that intimate correspondence, particularly love-letters, are a good source of information concerning the state of the spoken language before it was possible to capture this on tape, theatre could be said to aim at echoing spoken modes and to reflect spoken usage. Second, the relatively restricted numbers of examples of quand mesme/quand même in theatrical works (639 occurrences) made a survey of all occurrences in this genre 
TABLE 3. Rates of occurrence of quand même per 10,000 words in FRANTEXT, according to genre of writing

\begin{tabular}{|c|c|c|c|c|c|}
\hline Genre & $\begin{array}{l}\text { Number } \\
\text { of Texts }\end{array}$ & Word Count & $\begin{array}{c}\text { Occurrences } \\
\text { of quand } \\
\text { mesme }\end{array}$ & $\begin{array}{c}\text { Occurrences } \\
\text { of quand } \\
\text { même }\end{array}$ & $\begin{array}{c}\text { Rate of } \\
\text { Occurrence of } \\
\text { quand même } \\
\text { per } 10,000 \text { words }\end{array}$ \\
\hline Eloquence & 50 & 670,101 & 0 & 5 & 0.074 \\
\hline Traité & 785 & $52,315,159$ & 77 & 625 & 0.134 \\
\hline Essai & 1055 & $61,812,732$ & 79 & 767 & 0.136 \\
\hline Mémoires & 162 & $19,778,160$ & 5 & 284 & 0.146 \\
\hline Poésie & 469 & $10,086,949$ & 15 & 180 & 0.193 \\
\hline Récit de voyage & 53 & $4,824,880$ & 2 & 94 & 0.198 \\
\hline Pamphlet & 20 & $1,391,807$ & 2 & 33 & 0.251 \\
\hline Théâtre & 639 & $13,441,276$ & 38 & 319 & 0.265 \\
\hline Correspondance & 154 & $11,895,860$ & 14 & 374 & 0.326 \\
\hline Roman & 1054 & $90,780,696$ & 55 & 5066 & 0.564 \\
\hline
\end{tabular}

TABLE 4. Rates of occurrence of quand même per 10,000 words in the genre

"Théâtre" in FRANTEXT, across the centuries

\begin{tabular}{lccccc}
\hline \hline Period & \multicolumn{1}{c}{$\begin{array}{c}\text { Number } \\
\text { of Texts }\end{array}$} & Word Count & $\begin{array}{c}\text { Number of } \\
\text { Occurrences of } \\
\text { quand mesme }\end{array}$ & $\begin{array}{c}\text { Number of } \\
\text { Occurrences of } \\
\text { quand même }\end{array}$ & $\begin{array}{c}\text { Rate of } \\
\text { Ouand même of } \\
\text { per 10,000 words }\end{array}$ \\
\hline $1500-1599$ & 51 & 901,483 & 4 & 0 & 0.044 \\
$1600-1699$ & 194 & $3,654,023$ & 34 & 17 & 0.139 \\
$1700-1799$ & 143 & $2,481,474$ & 0 & 20 & 0.08 \\
$1800-1899$ & 112 & $2,510,296$ & 0 & 26 & 0.103 \\
$1900-1949$ & 102 & $2,812,147$ & 0 & 111 & 0.394 \\
$1950-2000$ & 40 & $1,163,658$ & 0 & 145 & 1.246 \\
\hline \hline
\end{tabular}

feasible. To survey all 5,066 examples in the novels is clearly a research study that goes beyond the scope of this article, albeit an interesting one. ${ }^{8}$

Table 4 charts the rate of occurrence of quand même in theatrical works from 1500-2000 and, in the main, it echoes the broader picture of Table 1. Occurrences increase overall from 0.04 per 10,000 words in the period from 1500-1599 to 1.2 in 1950-2000. The rates in this latter period are double those for the average over all genres in the same period and also double that for novels over the whole period. There is an interesting dip in the 18th and 19th centuries, and I can only speculate that this may reflect the somewhat more formal dramatic works of the writers of this time.

Table 5 charts the occurrences of quand mesme/même in theatrical works through the centuries with an indication of its grammatical and functional usage. 
TABLE 5. Number and relative percentage rates of occurrence of quand mesme/quand même in theatrical works in FRANTEXT, used as conjunctions with a concessive vs. temporal function or adverbs with an adversative vs. relational function, from 1500-2000

\begin{tabular}{|c|c|c|c|c|c|c|c|c|c|c|c|c|}
\hline \multirow[b]{3}{*}{ Period } & \multicolumn{6}{|c|}{ Conjunctions } & \multicolumn{6}{|c|}{ Adverbs } \\
\hline & \multicolumn{2}{|c|}{ Concessive } & \multicolumn{2}{|c|}{$\begin{array}{l}\text { Temporal or } \\
\text { Contrastive }\end{array}$} & \multicolumn{2}{|c|}{ Ambiguous } & \multicolumn{2}{|c|}{ Adversative } & \multicolumn{2}{|c|}{ Relational } & \multicolumn{2}{|c|}{ Exclamatory } \\
\hline & $N$ & $\%$ & $N$ & $\%$ & $N$ & $\%$ & $N$ & $\%$ & $N$ & $\%$ & $N$ & $\%$ \\
\hline $1500-1599$ & 4 & 100 & - & - & - & - & - & - & - & - & - & - \\
\hline $1600-1699$ & 47 & 92 & 1 & 2 & 3 & 6 & - & - & - & - & - & - \\
\hline $1700-1799$ & 19 & 95 & 1 & 5 & - & - & - & - & - & - & - & - \\
\hline $1800-1899$ & 14 & 54 & - & - & - & - & 11 & 42 & - & - & 1 & 4 \\
\hline $1900-1949$ & 9 & 8 & - & - & - & - & 61 & 55 & 36 & 32 & 5 & 5 \\
\hline $1950-2000$ & 8 & 0.5 & - & - & - & - & 64 & 44 & 72 & 50 & 1 & 0.7 \\
\hline
\end{tabular}

In the early period, the vast majority of the occurrences of quand mesme/quand même are conjunctions and are followed by a conditional tense (mainly present conditional, with a very small proportion of past conditional forms) and can be glossed "even if" / "even though." All four examples of quand mesme in the 16th century are attributable to Etienne Jodelle. In the 17 th century plays, quand mesme/ même continues to be used as a conjunction with a conditional tense, indicating its irrealis, conditional force. A typical example is:

Je prépare un discours qui la pourroit toucher

Quand mesme au lieu d'un coeur elle auroit un rocher.

(Du Ryer, Pierre, Les vendanges de Suresne, 1636, page 62, Acte 1, scène iv (vi))

When quand mesme/même occurs with a nonconditional tense, it is most easily interpreted as a temporal conjunction with intensifer as in:

Malgré son désir

Je les conserveray jusqu' au dernier souspir

Et quand mesme la mort aura finy mon terme

Sous la tombe avec moy je veux qu'on les enferme.

(L'Estoile, Claude de, Intrigue des Filous, 1648, page 88, Acte IIII, scène deuxiesme)

A few of the examples of quand mesme/même followed by verbs that are not conditional are ambiguous and can be interpreted as temporal or concessive, as in the following example:

Et quand mesme elle a sceu qu'avec impatience

Vous faisiez demander un moment d'audiance

Elle m'a commandé de vous faire sçavoir

Qu'elle est avec le Prince, et ne sçauroit vous voir.

(Quinault, Philippe, Astrate, roy de Tyr, 1665, page 38, Acte III scène II) 
In the 18th century, as well, all examples are conjunctions and the vast majority are concessive. In some cases, quand même appears to be more easily interpretable as contrastive, rather than concessive, as in the following example:

Et quand même nous ne réussirions pas, nos petites-filles réussiront.

(Marivaux, La Colonie, 1750, page 1851/Scène première)

However, as Table 5 shows, the vast majority of examples from this period are concessive conjunctions.

It is in the 19th century that the first adverbial usages of quand même begin to occur - and in quite large numbers. Overall, 54\% of occurrences are conjunctions and $42 \%$ are adverbs. Most of these adverbs still retain a strong and explicit adversative sense and can be translated "all the same," as in the following example:

Quand la comtesse arrivera, qu'elle ignore la présence de sa mari dans la maison, et qu'on la fasse entrer ici quand même.

(Dumas fils, Alexandre, L'ami des femmes, 1869, page 188, Acte V, scène III)

There is a sense of ellipsis here that we can reconstitute as "quand même elle ignorerait la présence de son mari."

It is only in the early years of the 20th century that quand même is used as an adverb in a relational way and no longer retains a clearly adversative quality. The conjunctival use of the term has dropped considerably: only $8 \%$ of occurrences are conjunctival, $55 \%$ of occurrences are adverbial and adversative, while $32 \%$ are relational. The latter uses can either be boosting or hedging. By the second half of the 20th century, conjunctive uses have dropped to $0.5 \%$ of all occurrences (mainly in the works of Albert Camus), adversative adverbial uses have dropped to $44 \%$, and relational uses have come to the fore, at $50 \%$. Though the rate of adverbial (and in particular relational) quand même usage is at its highest level from a historical point of view in the plays from 1950-2000, it is still only 1.16 per 10,000 words. Rates are consistently far higher in the spoken corpora surveyed, as we shall see next. ${ }^{9}$

Survey of rates of occurrence of quand même in the Orléans and Bristol Corpora

Appendix A charts the raw numbers of occurrences and distributional frequencies of quand même, adversative quand même, and relational quand même for each of the 79 subjects in the selected subsections of the two corpora. There is a wide range in the frequency with which speakers use quand même from 1 to 65 per 10,000 words. Both Macaulay (2002b:365), in his study of you know, and Vincent and Sankoff (1992:207), in their study of punctors, show a similar range of use of such markers. There is some evidence that use of such hedging or relational particles may be idiolectal (see Delomier, 1999:138 on hein, which she claimed is "largement présent dans le discours de certains locuteurs qui n'en ont souvent pas conscience"). Such individual variation makes averaging in terms of class and/or 
TABLE 6. Rates of occurrence of quand même, adversative quand même and relational quand même per 10,000 words in the Orléans (1968-71) and Bristol (1988-1991) Corpora

\begin{tabular}{lcc}
\hline \hline & Orléans Corpus & Bristol Corpus \\
\hline quand même & 14.38 & 23.10 \\
Adversative quand même & 5.16 & 8.21 \\
Relational quand même & 9.22 & 14.90 \\
\hline \hline
\end{tabular}

sex appear somewhat meaningless as large standard deviations are obscured in the averaging process. However, overall tendencies may be tentatively explored.

Mean rates of usage of quand même in the spoken corpus (conflating the data from the Orléans and Bristol Corpora) are 19 occurrences per 10,000 words, 7 (37\%) for adversative, and $12(63 \%)$ for relational quand même. This is considerably higher than the most recent, highest, rate of occurrence in the written theatrical works for 1950-2000 (1.246), and the proportion of adversative to relational usages shows an even more marked shift in the direction of the relational sense. Table 6 shows the rates of quand même in the two corpora. It is clear that rates are increasing and that this is particularly the case for relational quand même. As the data did not have a normal distribution (they were negatively skewed), the nonparametric Mann-Whitney test was used to check for statistical significance. In so far as this could be said to be reflected in the difference between the Orléans (1968) Corpus and the Bristol (1988) Corpus, the rise in frequency of quand même is statistically significant ( $p=.015$ ).

The full results, subdivided according to corpus, sex, and educational background, with values for $N$ (raw number of occurrences) and $r$ (rate of occurrence per 10,000 words), are set out in Appendix B. Figures 1-7 display the data in a more visual form. If we conflate the spoken data from the two corpora and consider them as being representative of the speech of the population of France in the second half of the 20th century, in however imperfect a way, we can see, in Figure 1, that the mid-educated group use quand même to a greater extent overall, and that relational quand même outweighs adversative quand même in all education groups, but particularly in the mid-educated group. The difference between education groups 1 and 2 on relational quand même is statistically significant $(p=.032)$.

Women appear to use quand même marginally more than men, particularly in its relational form, and there is an interesting class/sex configuration, in that the most highly educated men have somewhat depressed rates of quand même usage. Figure 2 shows that this is particularly the case for relational quand même. This difference between the most educated men and women's usage is statistically significant $(p=.043)$.

When we come to compare data from the earlier Orléans Corpus with the later Bristol Corpus in Figure 3, we see that overall rates of quand même have increased $(p=.015)$ and that women appear to be in the vanguard of this change with higher rates of usage in both corpora. 


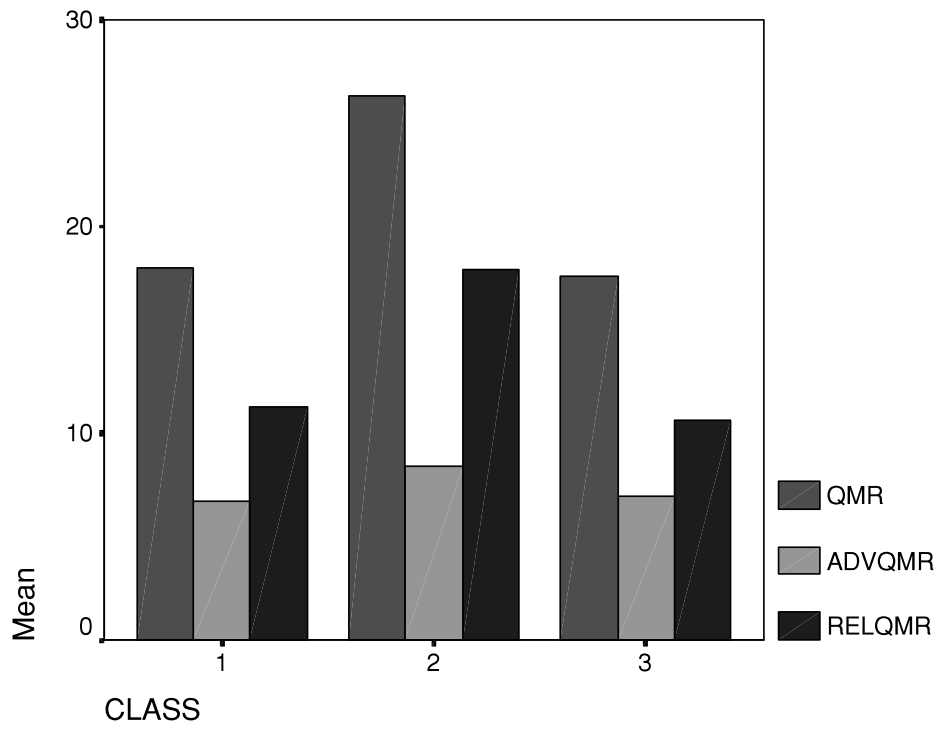

FIGURE 1. Mean rates of occurrence of quand même per 10,000 words in the Orléans and Bristol Corpora, subdivided according to educational background $(1=$ speakers who left school without the baccalauréat; $2=$ speakers who gained the baccalauréat; $3=$ speakers who have a university degree or degrees).

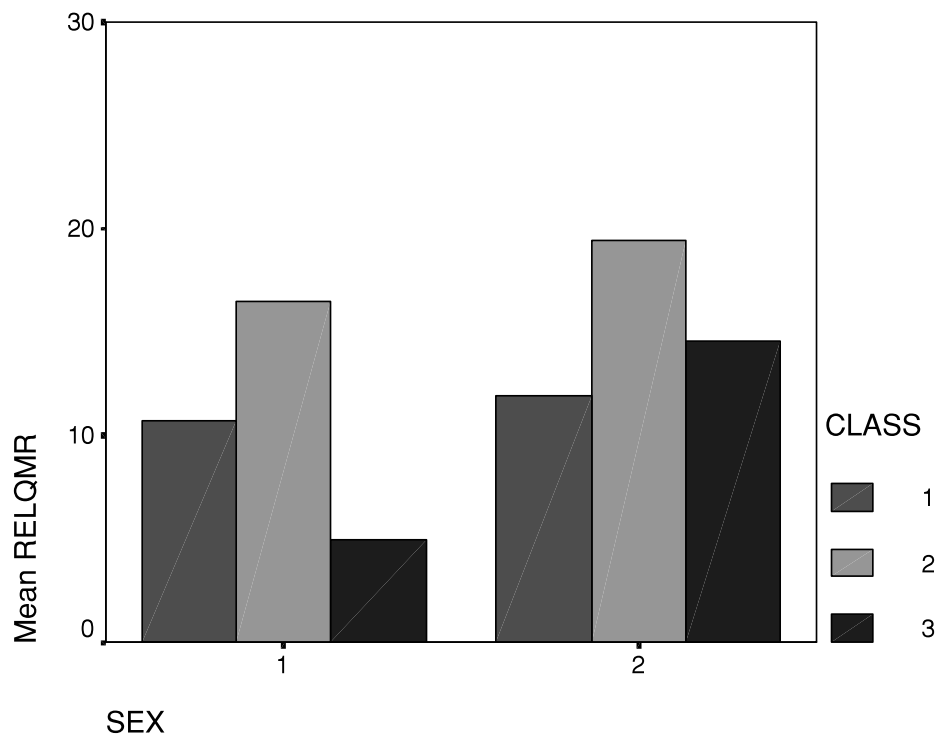

FIGURE 2. Mean rates of occurrence of relational quand même per 10,000 words in the Orléans and Bristol Corpora, subdivided according to sex ( $1=$ males; $2=$ females $)$ and educational background $(1=$ speakers who left school without the baccalauréat; 2 = speakers who gained the baccalauréat; 3 = speakers who have a university degree or degrees). 


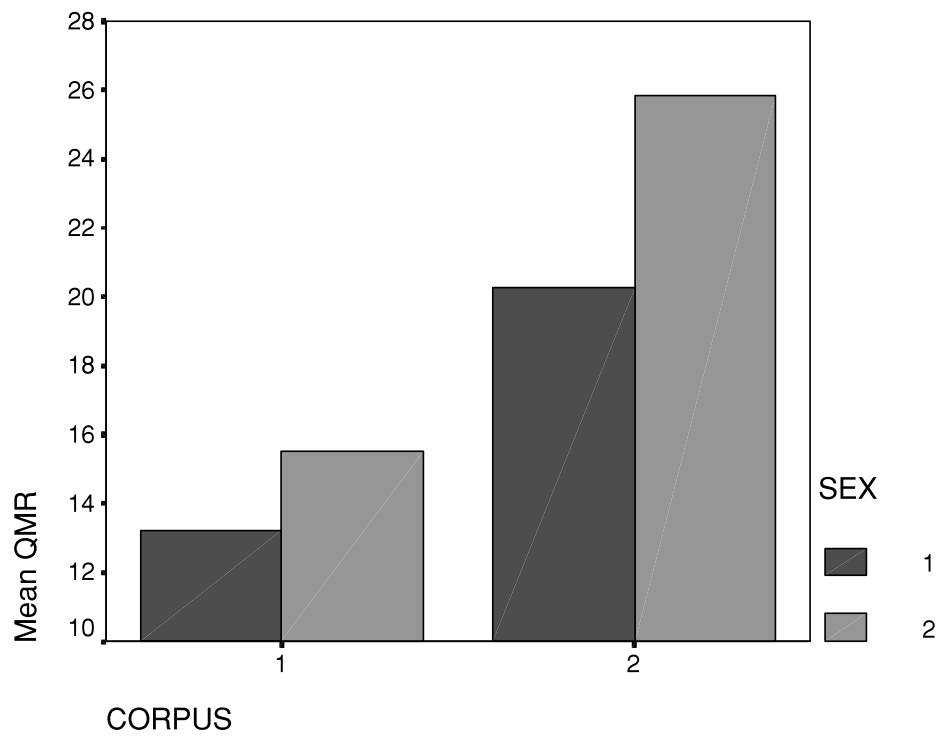

FIGURE 3. Mean rates of occurrence of quand même per 10,000 words in the Orléans (1) and Bristol (2) Corpora, subdivided according to sex ( $1=$ males; $2=$ females).

\section{Orléans Corpus}

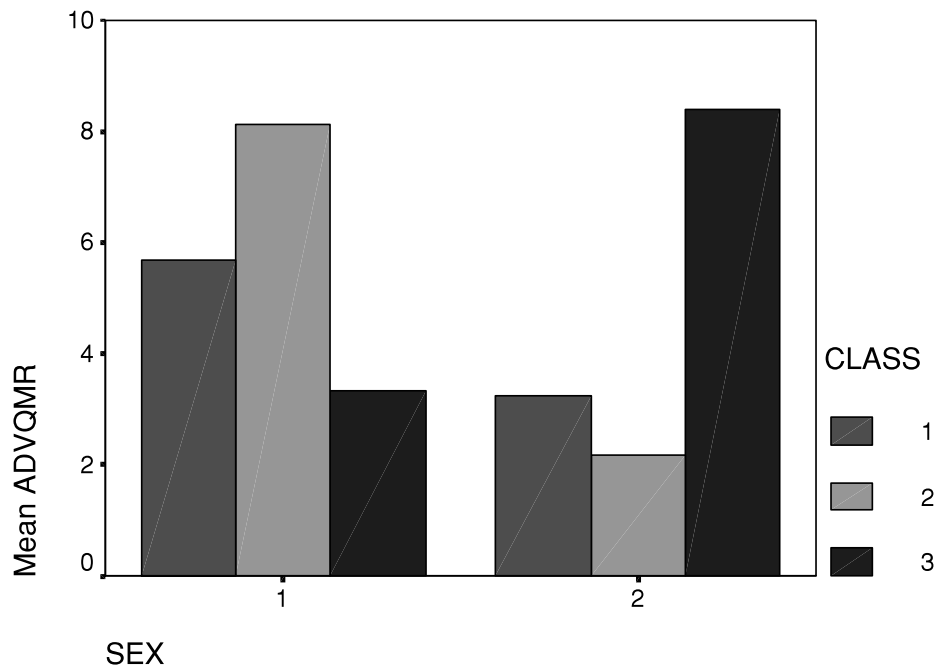

FIGURE 4. Mean rates of occurrence of adversative quand même per 10,000 words in the Orléans Corpus, subdivided according to sex $(1=$ male; $2=$ female $)$ and educational background $(1=$ speakers who left school without the baccalauréat; 2 = speakers who gained the baccalauréat; 3 = speakers who have a university degree or degrees). 
Orléans Corpus

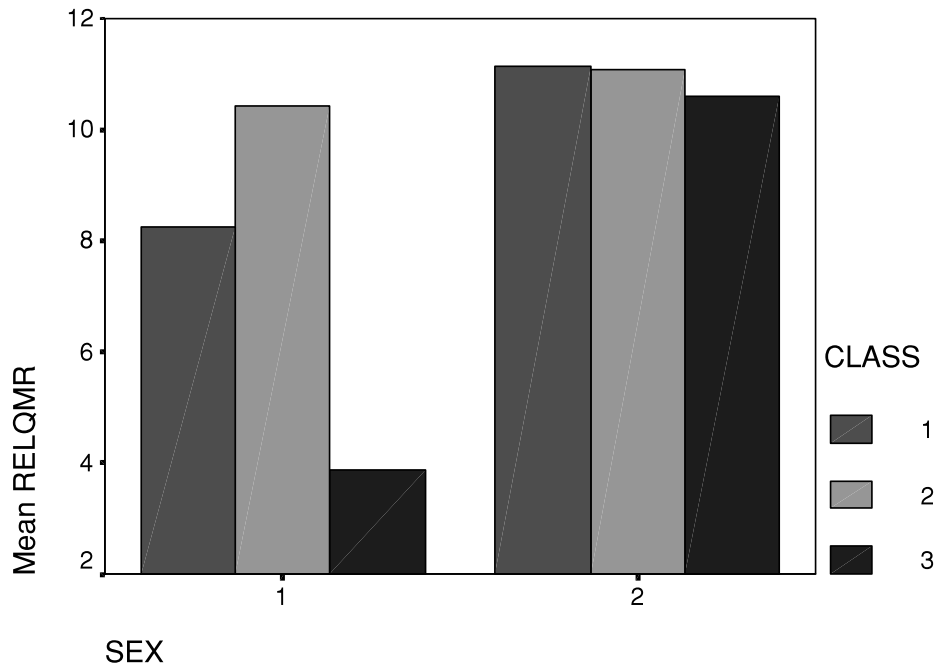

FIGURE 5. Mean rates of occurrence of relational quand même per 10,000 words in the Orléans Corpus, subdivided according to sex $(1=$ male; $2=$ female $)$ and educational background $(1=$ speakers who left school without the baccalauréat; $2=$ speakers who gained the baccalauréat; 3 = speakers who have a university degree or degrees).

\section{Bristol Corpus}

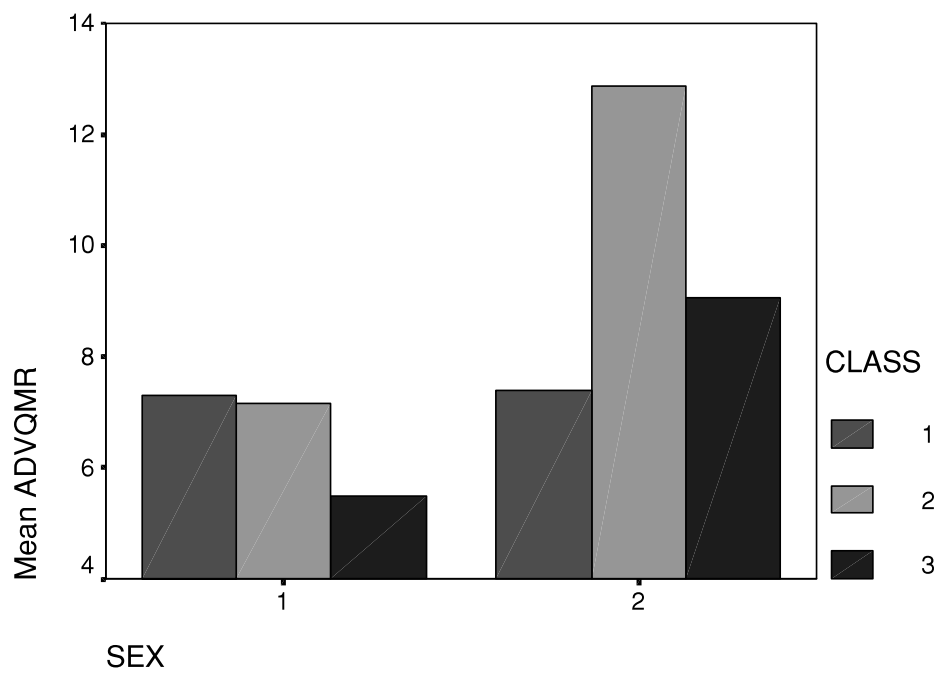

FIGURE 6. Mean rates of occurrence of adversative quand même per 10,000 words in the Bristol Corpus, subdivided according to sex $(1=$ male; $2=$ female $)$ and educational background $(1=$ speakers who left school without the baccalauréat; 2 = speakers who gained the baccalauréat; 3 = speakers who have a university degree or degrees). 


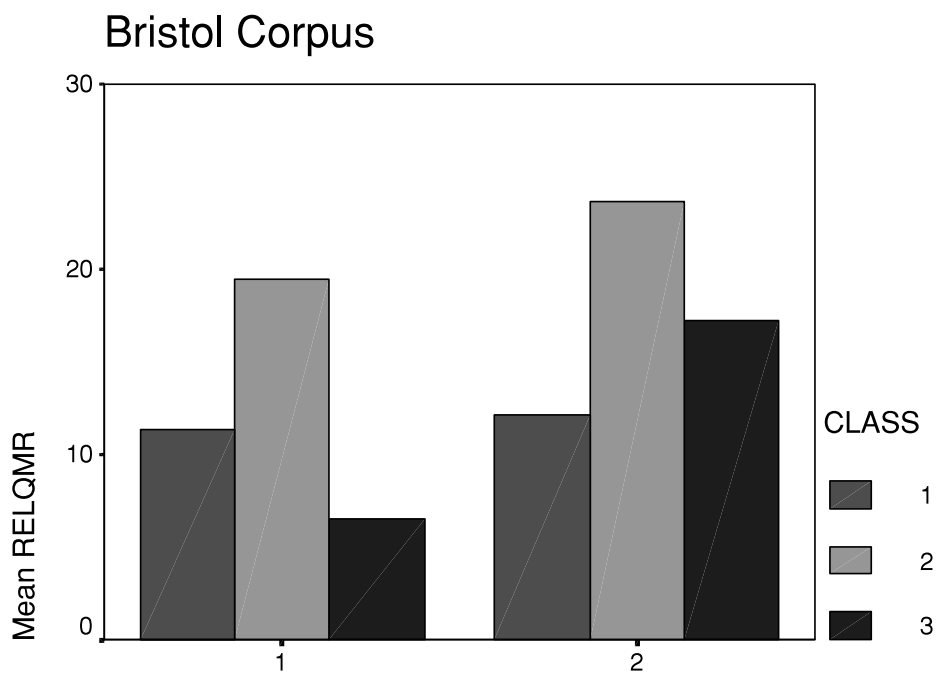

SEX

FIGURE 7. Mean rates of occurrence of relational quand même per 10,000 words in the Bristol Corpus, subdivided according to sex $(1=$ male; $2=$ female $)$ and educational background $(1=$ speakers who left school without the baccalauréat; $2=$ speakers who gained the baccalauréat; 3 = speakers who have a university degree or degrees).

Figures $4-7$, moreover, reveal a potentially very interesting sex/class development. In the Orléans Corpus (Figures 4 \& 5), the less educated men have higher rates of adversative quand même usage, whereas it is the most educated women who use adversative quand même to the greatest extent. Relational quand même is used equally by all speakers, apart from the most educated men who eschew it. The difference between the rates of the most educated men and the most educated women does not, however, reach statistical significance. In the Bristol Corpus (Figures $6 \& 7$ ), adversative quand même is championed by women in the mideducated group. Relational quand même is also a form favored by both men and women in the mid-educated groups ( $p=.01$ in a comparison of education groups 1 and 2) and, although it appears to be favored by the most educated women, it is eschewed by the most educated men (a difference that does not, however, reach statistical significance).

In conclusion, we can say that adverbial quand même is a form that is in progression. It occurs far more frequently in the spoken than in the written language, a relational sense is overtaking an adversative sense, and female and mideducated speakers are in the vanguard of this change. The most educated men, for whom quand même may be a stigmatized form, appear to eschew relational quand même.

If relational quand même is, indeed, a form that is spreading, this would seem to corroborate Labov's assertions concerning the pivotal role of the lower-middle 
class "early adopters" in the propagation of language change. Moreover, according to Labov's (1990) Principle II, in the majority of linguistic changes, women use a higher frequency of the incoming forms than men. Women have reputedly a "clear advantage over men in terms of their sociolinguistic competence" (Chambers, 1995:132) and this might go some way in explaining their relative ease in adopting the new form-function configuration. Labov (2001:366) addressed the question of what he calls the "Gender Paradox," whereby women seem to be more conservative than men, using more standard variants, but are also more progressive than men, because they adopt new variants more quickly. Labov suggested as a resolution of this apparent contradiction that: "Women deviate less than men from linguistic norms when the deviations are overtly proscribed, but more than men when the deviations are not proscribed."

The use of hedging particles such as quand même would most certainly be proscribed in formal written language, and excessive use of them in the spoken language might well be frowned upon. However, because of women's slightly greater cerebral propensity towards "empathizing" (see Baron-Cohen, 2003), they are more likely to employ quand même in a pragmatic and relational manner. Sex and social class play a fundamental role in the perceived "respectability" (overt prestige) of a form and in promoting its wider-spread use throughout the population. Women give a form overt prestige. Milroy and Milroy (e.g., Milroy \& Milroy, 1997; Milroy et al., 1994) argued that it is misleading to say that women favor prestige forms. The cause and effect are, in fact, the reverse. The forms that women use become overtly prestigious in the community. These forms (possibly attached to a different function) are then adopted in a change "from below" by both men and women. In the case of a pragmaticalizing form, recruited for relational purposes, women are likely to be in the vanguard in both innovation and propagation, for these reasons.

\section{Summary}

Quand même is currently polysemous or multifunctional. In the spoken language, and in written language that reflects it, weight appears to be shifting from a propositional to a relational (bleached) form. It is hoped that further data collection and ongoing exploration of the role of quand même in everyday conversation may continue to test the hypothesis that quand même itself is undergoing a gradual pragmaticalization, as its underlying "apologetic" semantic core makes it eminently vulnerable to recruitment as a hedging particle and that its strong concessive or adversative sense is gradually being transferred to other lexical items, such as pourtant. The process is a long and slow one and, as Hopper and Traugott (1993:95) pointed out, there is no guarantee that it will ever reach its logical conclusion:

Changes do not have to occur. They do not have to go to completion, they do not have to move all the way along a cline [...] the outcome of grammaticalization is quite often a ragged and incomplete subsystem that is not evidently moving in some identifiable direction. 
In an attempt to find regularity in the pragmatico-semantic changes apparently undergone by quand même, I return, in my conclusion, to notions of social integration and politeness.

C O N CLUS I O N

This article attempts to draw attention to the role of hedging particles as a means of mediating politeness, as much through social indexation, which such markers may confer, as through their face-enhancing properties. It aims to demonstrate that the overwhelmingly ubiquitous considerations of politeness in everyday interaction may lead to a rise in the distributional frequency of particular invited inferences. In the case of quand même, it is a rise in the frequency of the relational sense and a corresponding decrease in the adversative sense. Haspelmath (1999:1062) argued that the semantic bleaching or generalization, so often observed in the development from a lexical to a functional category, does not seem to be a consequence of routinization, but a prerequisite for it: "Semantic generalization or bleaching is usually a prerequisite for use in a basic discourse function, that is, for the increase in frequency that triggers the other changes."

This process seems to have been particularly well-illustrated in the grammaticalization and pragmaticalization of quand même, as it developed from a form that was solely concessive and conjunctival in the 18th century and whose frequency of occurrence as an adverb rose in the 19th century. As quand même adverbialized, it was increasingly employed as a relational hedging particle, and though this usage coexists with its canonical adversative one, the conjunctival usage has all but disappeared, even in more formal styles of writing. It is my contention that at the far right of the trajectory of semantic change, the combined insights from politeness theory (Brown \& Levinson, 1987; Eelen, 2001), Milroyan notions of social networks (e.g., Milroy, 2002), sociolinguistic notions of salience (e.g., Kerswill \& Williams, 2002), Heine, Claudi, and Hünnemeyer's (1991) ground-breaking ideas on the conceptual network of grammaticalization and the role of routinization, coupled with Traugott and Dasher's (2002) Invited Inferencing Theory of Semantic Change, can shed considerable light on the processes of innovation and propagation. Each approach underlines the primacy of human cognition and human sociability as the motor of change. What happens in terms of grammaticalization, phonetic reduction, and coalescence may well follow internal structural constraints. The underlying motor for change is, however, pragmatico-semantic, cognitive (see Sweetser, 1990:1-22), possibly ludic, and motivated by considerations of face and social standing. If, as Haspelmath argued, lexical items must lose their specific semantic content and generalize to be used in a basic discourse function (for on-line editing or, indeed, polite hedging), this process is explicable by reference to Traugott and Dasher's (2002) pragmatic notion of Invited Inferencing. As polite formulae are very frequent in everyday interaction, routinization quickly confirms a newly recruited hedging particle, which loses its original pragmatic salience in the manner commonly observed in grammaticalization. So, it seems that, in certain cases, politeness theory may help explicate innovation. It may also help to 
explain propagation, in that human society is apt to splinter into various identity groups, and, like phonological features, "bleached" hedging particles can be markers of social identity. It is at this point that factors relating to social indexation will play their role in the promotion, or demotion, of particular linguistic forms in the utterances of particular speakers in particular circumstances. In this sense, politeness theory can throw light on propagation, for it is social indexation (having to do with the maintenance of power and distance) that underlies the now well-known relationship between synchronic and diachronic variation. At the non-truthconditional, procedural, scope-over-discourse, and intersubjective far right of the spectrum of semantic change, politeness theory, with its dual conceptualization having to do with conflict avoidance (sociability) and social indexation, provides a bridge linking pragmatics and sociolinguistics.

\section{NOTES}

1. Milroy (1993) made a similar key distinction between "speakers" and "systems," "innovation" and "change."

2. There are, indeed, no instances in either of the spoken corpora of the type of dialogal quand même, which is used as a reaction to a declaration or action of another, encapsulated in the exclamation: Mais quand même! This dialogal usage of quand même reveals, however, its highly oppositional function and demonstrates that it cannot be considered as a conjunction.

3. Available at http://atilf.atilf.fr/.

4. Available from http://bach.arts.kuleuven.ac.be/lancom.

5. Available from http://www.uwe.ac.uk/hlss/languages/research/staff/CORPUS.pdf.

6. Macaulay (2002:299) made four recommendations, which I full-heartedly endorse and to which I should like to add the following comments. We need more data. This is particularly crucial for spoken hexagonal French where on-line corpora are few and far between. Amassing stores of comparative data. I would welcome approaches from researchers with a view to creating such a data bank for discourse features of spoken French in general and pragmatic expressions in particular. The usefulness of the computer. This assertion is undoubtedly true where finding and counting particular linguistic items are concerned. Where functional attribution and insights into metaphorical transfer are required, however, substantial legwork by a linguistically trained researcher remains indispensable. 7. Veland (1998) used similar criteria in his distinction between the direct and indirect concessive values of quand même and tout de même, employing the test involving "la possibilité ou non d'une reformulation en bien que." (1998:240).

8. Veland (1998) surveyed usages of quand même and tout de même in ten 19th century novels and noted that: $62 \%$ of occurrences are to be found in direct speech which "indique probablement que les marqueurs du type en question ont pris naissance dans la langue parlée" (1998:237); frequencies doubled in the 150 years from $1800-1950$, and, whereas in the $19^{\text {th }}$ century, tout de même constituted $70 \%$ of the total, in the $20^{\text {th }}$ century, quand même represented $65 \%$.

9. Despite its limitations, the present study provides much greater substantiation than Fónagy (1995) did of the evolution in the use of quand même from a concessive to a more "modal" usage. As Veland (1998:219) reported, Fónagy's conclusion, based on a comparison of a specimen of spoken language with the first few pages of Saussure's Cours de linguistique general, does not lead to the more generalized conclusion that the adverb is rising in distributional frequency.

\section{REFER E NCES}

Baron-Cohen, Simon. (2003). The essential difference: Men, women and the extreme male brain. London: Allen Lane.

Beeching, Kate. (2002). Gender, politeness and pragmatic particles in French. Amsterdam: Benjamins. Beeching, Kate, \& Le Guilloux, Isabelle. (1990). Ça se dit et ça s'écrit. Oxford: Oxford University Press.

(1993). La passerelle. Cambridge: Cambridge University Press.

Brown, Penelope, \& Levinson, Stephen. (1987). Politeness. Cambridge: Cambridge University Press. Chambers, J. K. (1995). Sociolinguistic theory. Oxford: Blackwell. 
Croft, William. (2000). Explaining language change. An evolutionary aproach. Harlow: Longman.

Delomier, Dominique. (1999). Hein particule désémantisée ou indice de consensualité? In Faits de langue. Revue de linguistique (No. 13). Oral-Ecrit: Formes et theories. Paris: Ophrys.

Eelen, Gino. (2001). A critique of politeness theories. Manchester: St. Jerome Publishing.

Fónagy, I. (1995). Figement et mouvement; changements lexicaux en cours dans le français contemporain. Revue Romane 30:163-204.

Grieve, James. (1996). Dictionary of contemporary French connectors. London: Routledge.

Haspelmath, Martin. (1999). Why is grammaticalization irreversible? Linguistics 37(6): $1043-1068$.

Heine, Bernd, Claudi, Ulrike, \& Hünnemeyer, Friederieke. (1991). Grammaticalization: A conceptual framework. Chicago: University of Chicago Press.

Hopper, Paul J., \& Traugott, Elizabeth, Closs. (1993). Grammaticalization. Cambridge: Cambridge University Press.

Kasper, Gabriele. (1990). Linguistic politeness: Current research issues. Journal of Pragmatics 14:193-218.

Kerbrat-Orecchioni, Catherine. (1997). A multi-level approach in the study of talk-in-interaction. Pragmatics 7(1):1-20.

Kerswill, Paul, \& Williams, Ann. (2002). "Salience" as an explanatory factor in language change: Evidence from dialect levelling in urban England. In Mari C. Jones \& Edith Esch (eds.), Language change: The interplay of internal, external and extra-linguistic factors. Berlin: Mouton de Gruyter. $81-110$.

Labov, William. (1990). The intersection of sex and social class in the course of linguistic change. Language Variation and Change 2:205-254.

(2001). Principles of linguistic change (Vol. 2): Social factors. Oxford: Blackwell.

Macaulay, Ronald. (2002a). Discourse variation. In J. K. Chambers, Peter Trudgill, \& Natalie SchillingEstes (eds.), The handbook of language variation and change. Oxford: Blackwell. 283-305. (2002b). You know, it depends. Journal of Pragmatics 34:749-767.

Milroy, James. (1992). Linguistic variation and change. Oxford: Blackwell. (1993). On the social origins of language change. In Charles Jones (ed.), Historical linguistics. Problems and perspectives. Harlow: Longman.

Milroy, James, \& Milroy, Lesley. (1997). Varieties and variation. In Florian Coulmas (ed.), The handbook of sociolinguistics. Oxford: Blackwell.

Milroy, James, Milroy, Lesley, Hartley, Sue, \& Walshaw, David. (1994). Glottal stops and Tyneside glottalization: Cometing patterns of variation and change in British English. Language Variation and Change 6:327-358.

Milroy, Lesley. (2002). Social Networks. In J. K. Chambers, Peter Trudgill, \& Natalie Schilling-Estes (eds.), The handbook of language variation and change. Oxford: Blackwell. 549-572.

Moeschler, Jacques, \& de Spengler, Nina. (1981). Quand même: De la concession à la réfutation. Cahiers de Linguistique Française 2:93-112.

Posner, Rebecca. (1997). Linguistic change in French. Oxford: Clarendon.

Spencer-Oatey, Helen. (2000). Rapport-management: A framework for Analysis. In Helen SpencerOatey (ed.). Culturally speaking: Managing rapport through talk across cultures. London: Continuum. 11-46.

Sweetser, Eve. (1990). From etymology to pragmatics: Metaphorical and cultural aspects of semantic structure. Cambridge: Cambridge University Press.

Traugott, Elizabeth Closs. (1982). From propositional to textual and expressive meanings: Some semantic-pragmatic aspects of grammaticalization. In Winifred P. Lehmann \& Yakov Malkiel (eds.), Perspectives on historical linguistics. Amsterdam Studies in the Theory and History of Linguistic Science IV. Current Issues in Linguistic Theory (Vol. 24). Amsterdam: Benjamins. 245-272.

Traugott, Elizabeth Closs, \& Dasher, Richard B. (2002). Regularity in semantic change. Cambridge: Cambridge University Press.

Veland, Reidar. (1998). Quand même et tout de même: Concessivité, synonymie, évolution. Revue Romane 33(2):217-247.

Vincent, Diane, \& Sankoff, David. (1992). Punctors: A pragmatic variable. Language Variation and Change 4:205-216.

Waltereit, Richard. (2001). Modal particles and their functional equivalents: A speech-act-theoretic approach. Journal of Pragmatics 33:1391-1417.

Wolfson, Nessa. (1997). Speech events and natural speech. In Nicholas Coupland \& Adam Jaworski (eds.), Sociolinguistics: A reader and course-book. Basingstoke: Macmillan. 116-125. 
A P PENDIX A

\begin{tabular}{|c|c|c|c|c|c|c|c|c|c|c|}
\hline \multirow[b]{2}{*}{ ID } & \multirow[b]{2}{*}{ Corpus } & \multirow[b]{2}{*}{ Sex } & \multirow[b]{2}{*}{ Class } & \multirow[b]{2}{*}{ Words } & \multicolumn{2}{|c|}{ QM } & \multicolumn{2}{|c|}{ QMADV } & \multicolumn{2}{|c|}{ QMREL } \\
\hline & & & & & $N$ & $r$ & $N$ & $r$ & $N$ & $r$ \\
\hline 1.00 & 1 & Male & 1 & 13189 & 45.00 & 34.12 & 22.00 & 16.68 & 23.00 & 17.44 \\
\hline 6.00 & 1 & Male & 1 & 11143 & 8.00 & 7.18 & 3.00 & 2.69 & 5.00 & 4.49 \\
\hline 44.00 & 1 & Male & 1 & 7016. & 9.00 & 12.83 & 2.00 & 2.85 & 7.00 & 9.98 \\
\hline 14.00 & 1 & Male & 1 & 18262 & 3.00 & 1.64 & 1.00 & .55 & 2.00 & 1.10 \\
\hline 140.00 & 1 & Female & 1 & 6211 & 2.00 & 3.22 & .00 & .00 & 2.00 & 3.22 \\
\hline 105.00 & 1 & Female & 1 & 16920 & 27.00 & 15.96 & 7.00 & 4.14 & 20.00 & 11.82 \\
\hline 9.00 & 1 & Female & 1 & 18361 & 60.00 & 32.68 & 11.00 & 5.99 & 49.00 & 26.69 \\
\hline 49.00 & 1 & Female & 1 & 10719 & 6.00 & 5.60 & 3.00 & 2.80 & 3.00 & 2.80 \\
\hline 51.00 & 1 & Male & 2 & 18009 & 47.00 & 26.10 & 23.00 & 12.77 & 24.00 & 13.33 \\
\hline 11.00 & 1 & Male & 2 & 14252 & 46.00 & 32.28 & 18.00 & 12.63 & 28.00 & 19.65 \\
\hline 52.00 & 1 & Male & 2 & 10964 & 5.00 & 4.56 & 3.00 & 2.74 & 2.00 & 1.82 \\
\hline 13.00 & 1 & Male & 2 & 11598 & 13.00 & 11.21 & 5.00 & 4.31 & 8.00 & 6.90 \\
\hline 46.00 & 1 & Female & 2 & 17809 & 2.00 & 1.12 & .00 & .00 & 2.00 & 1.12 \\
\hline 17.00 & 1 & Female & 2 & 15282 & 6.00 & 3.93 & 3.00 & 1.96 & 3.00 & 1.96 \\
\hline 15.00 & 1 & Female & 2 & 10491 & 44.00 & 41.94 & 5.00 & 4.77 & 39.00 & 37.17 \\
\hline 7.00 & 1 & Female & 2 & 4978 & 3.00 & 6.03 & 1.00 & 2.01 & 2.00 & 4.02 \\
\hline 4.00 & 1 & Male & 3 & 1672 & 31.00 & 18.53 & 12.00 & 7.17 & 19.00 & 11.36 \\
\hline 3.00 & 1 & Male & 3 & 5775 & 3.00 & 5.19 & 1.00 & 1.73 & 2.00 & 3.46 \\
\hline 12.00 & 1 & Male & 3 & 15808 & 5.00 & 3.16 & 4.00 & 2.53 & 1.00 & .63 \\
\hline 58.00 & 1 & Male & 3 & 10320 & 2.00 & 1.94 & 2.00 & 1.94 & .00 & .00 \\
\hline 88.00 & 1 & Female & 3 & 7407 & 7.00 & 9.45 & 5.00 & 6.75 & 2.00 & 2.70 \\
\hline 5.00 & 1 & Female & 3 & 13749 & 21.00 & 15.27 & 4.00 & 2.91 & 17.00 & 12.36 \\
\hline 72.00 & 1 & Female & 3 & 8410 & 12.00 & 14.27 & 9.00 & 10.70 & 3.00 & 3.57 \\
\hline 26.00 & 1 & Female & 3 & 18927 & 70.00 & 36.98 & 25.00 & 13.21 & 45.00 & 23.78 \\
\hline 1.00 & 2 & Male & 1 & 8052 & 4.00 & 4.97 & 1.00 & 1.24 & 3.00 & 3.73 \\
\hline 9.00 & 2 & Male & 1 & 461 & 3.00 & 65.08 & 1.00 & 21.69 & 2.00 & 43.38 \\
\hline 16.00 & 2 & Male & 1 & 8912 & 14.00 & 15.71 & .00 & .00 & 14.00 & 15.71 \\
\hline 23.00 & 2 & Male & 1 & 8766 & 2.00 & 2.28 & 1.00 & 1.14 & 1.00 & 1.14 \\
\hline 34.00 & 2 & Male & 1 & 1817 & 2.00 & 11.01 & .00 & .00 & 2.00 & 11.01 \\
\hline 36.00 & 2 & Male & 1 & 1509 & 1.0 & 6.63 & 1.00 & 6.63 & .00 & .00 \\
\hline 39.00 & 2 & Male & 1 & 7292 & 5.00 & 6.86 & 4.00 & 5.49 & 1.00 & 1.37 \\
\hline 43.00 & 2 & Male & 1 & 350 & 1.00 & 28.57 & .00 & .00 & 1.00 & 28.57 \\
\hline 44.00 & 2 & Male & 1 & 601 & 1.00 & 16.64 & 1.00 & 16.64 & .00 & .00 \\
\hline 51.00 & 2 & Male & 1 & 1925 & 2.00 & 10.39 & .00 & .00 & 2.00 & 10.39 \\
\hline 54.00 & 2 & Male & 1 & 805 & 4.00 & 49.69 & 1.00 & 12.42 & 3.00 & 37.27 \\
\hline 62.00 & 2 & Male & 1 & 719 & 3.00 & 41.72 & 3.00 & 41.72 & .00 & .00 \\
\hline 67.00 & 2 & Male & 1 & 1079 & 1.00 & 9.27 & .00 & .00 & 1.00 & 9.27 \\
\hline 73.00 & 2 & Male & 1 & 3791 & 2.00 & 5.28 & 1.00 & 2.64 & 1.00 & 2.64 \\
\hline 74.00 & 2 & Male & 1 & 2714 & 4.00 & 14.74 & 2.00 & 7.37 & 2.00 & 7.37 \\
\hline 85.00 & 2 & Male & 1 & 2041 & 2.00 & 9.80 & .00 & .00 & 2.00 & 9.80 \\
\hline 75.00 & 2 & Female & 1 & 295 & 1.00 & 33.90 & .00 & .00 & 1.00 & 33.90 \\
\hline 45.00 & 2 & Female & 1 & 1128 & 2.00 & 17.73 & .00 & .00 & 2.00 & 17.73 \\
\hline 40.00 & 2 & Female & 1 & 479 & 1.00 & 20.88 & 1.00 & 20.88 & .00 & .00 \\
\hline 7.00 & 2 & Female & 1 & 3072 & 6.00 & 19.53 & .00 & .00 & 6.0 & 19.53 \\
\hline 13.00 & 2 & Female & 1 & 838 & 1.00 & 11.93 & .00 & .00 & 1.00 & 11.93 \\
\hline 14.00 & 2 & Female & 1 & 413 & 1.00 & 24.21 & .00 & .00 & 1.00 & 24.21 \\
\hline 35.00 & 2 & Female & 1 & 1818 & 1.00 & 5.50 & 1.00 & 5.50 & .00 & .00 \\
\hline 47.00 & 2 & Female & 1 & 5407 & 9.00 & 16.65 & 3.00 & 5.55 & 6.00 & 11.10 \\
\hline 68.00 & 2 & Female & 1 & 533 & 3.00 & 56.29 & 1.00 & 18.76 & 2.00 & 37.52 \\
\hline 78.00 & 2 & Female & 1 & 1216 & 3.00 & 24.67 & 3.00 & 24.67 & .00 & .00 \\
\hline 88.00 & 2 & Female & 1 & 486 & 1.00 & 20.58 & 1.00 & 20.58 & .00 & .00 \\
\hline \multirow[t]{2}{*}{89.00} & 2 & Female & 1 & 3331 & 1.00 & 3.00 & .00 & .00 & 1.00 & 3.00 \\
\hline & & & & & & & & & \multicolumn{2}{|c|}{ (continued) } \\
\hline
\end{tabular}


Continued

\begin{tabular}{|c|c|c|c|c|c|c|c|c|c|c|}
\hline \multirow[b]{2}{*}{ ID } & \multirow[b]{2}{*}{ Corpus } & \multirow[b]{2}{*}{ Sex } & \multirow[b]{2}{*}{ Class } & \multirow[b]{2}{*}{ Words } & \multicolumn{2}{|c|}{$\mathrm{QM}$} & \multicolumn{2}{|c|}{ QMADV } & \multicolumn{2}{|c|}{ QMREL } \\
\hline & & & & & $N$ & $r$ & $N$ & $r$ & $N$ & $r$ \\
\hline 92.00 & 2 & Female & 1 & 2781 & 3.00 & 10.79 & 1.00 & 3.60 & 2.00 & 7.19 \\
\hline 93.00 & 2 & Female & 1 & 2628 & 2.00 & 7.61 & 1.00 & 3.81 & 1.00 & 3.81 \\
\hline 46.00 & 2 & Male & 2 & 2623 & 1.00 & 3.81 & .00 & .00 & 1.00 & 3.81 \\
\hline 15.00 & 2 & Male & 2 & 3444 & 5.00 & 14.52 & 1.00 & 2.90 & 4.00 & 11.61 \\
\hline 21.00 & 2 & Male & 2 & 601 & 3.00 & 49.92 & 2.00 & 33.28 & 1.00 & 16.64 \\
\hline 22.00 & 2 & Male & 2 & 1022 & 3.00 & 29.35 & .00 & .00 & 3.00 & 29.35 \\
\hline 25.00 & 2 & Male & 2 & 527 & 2.00 & 37.95 & .00 & .00 & 2.00 & 37.95 \\
\hline 29.00 & 2 & Male & 2 & 4007 & 5.00 & 12.48 & 1.00 & 2.50 & 4.00 & 9.98 \\
\hline 52.00 & 2 & Male & 2 & 1788 & 7.00 & 39.15 & 1.00 & 5.59 & 6.00 & 33.56 \\
\hline 66.00 & 2 & Male & 2 & 1548 & 4.00 & 25.84 & 2.00 & 12.92 & 2.00 & 12.92 \\
\hline 58.00 & 2 & Female & 2 & 2280 & 4.00 & 17.54 & 1.00 & 4.39 & 3.00 & 13.16 \\
\hline 59.00 & 2 & Female & 2 & 1009 & 4.00 & 39.64 & 1.00 & 9.91 & 3.00 & 29.73 \\
\hline 12.00 & 2 & Female & 2 & 1774 & 7.00 & 39.46 & .00 & .00 & 7.00 & 39.46 \\
\hline 4.00 & 2 & Female & 2 & 1252 & 5.00 & 39.94 & 1.00 & 7.99 & 4.00 & 31.95 \\
\hline 24.00 & 2 & Female & 2 & 1298 & 2.00 & 15.41 & .00 & .00 & 2.00 & 15.41 \\
\hline 77.00 & 2 & Female & 2 & 1681 & 11.00 & 65.44 & 11.00 & 65.44 & .00 & .00 \\
\hline 84.00 & 2 & Female & 2 & 3722 & 8.00 & 21.49 & 3.00 & 8.06 & 5.00 & 13.43 \\
\hline 95.00 & 2 & Female & 2 & 4143 & 22.00 & 53.10 & 3.00 & 7.24 & 19.00 & 45.86 \\
\hline 86.00 & 2 & Male & 3 & 1855 & 3.00 & 16.17 & 1.00 & 5.39 & 2.00 & 10.78 \\
\hline 83.00 & 2 & Male & 3 & 1567 & 2.00 & 12.76 & 1.00 & 6.38 & 1.00 & 6.38 \\
\hline 94.00 & 2 & Male & 3 & 4240 & 3.00 & 7.08 & 2.00 & 4.72 & 1.00 & 2.36 \\
\hline 5.00 & 2 & Female & 3 & 1833 & 8.00 & 43.64 & 1.00 & 5.46 & 7.00 & 38.19 \\
\hline 69.00 & 2 & Female & 3 & 3261 & 4.00 & 12.27 & 1.00 & 3.07 & 3.00 & 9.20 \\
\hline 76.00 & 2 & Female & 3 & 1512 & 4.00 & 26.46 & 1.00 & 6.61 & 3.00 & 19.84 \\
\hline 81.00 & 2 & Female & 3 & 1084 & 6.00 & 55.35 & 4.00 & 36.90 & 2.00 & 18.45 \\
\hline 87.00 & 2 & Female & 3 & 1211 & 2.00 & 16.52 & .00 & .00 & 2.00 & 16.52 \\
\hline 91.00 & 2 & Female & 3 & 8633 & 3.00 & 3.48 & 2.00 & 2.32 & 1.00 & 1.16 \\
\hline
\end{tabular}

A P PENDIX B

$N$ values for QM, AdvQM, and RelQM in both corpora

\begin{tabular}{lrrr}
\hline \hline & 1.00 & 2.00 & 3.00 \\
& Sum & Sum & Sum \\
\hline Males & 116.00 & 141.00 & 49.00 \\
& 44.00 & 56.00 & 23.00 \\
& 72.00 & 85.00 & 26.00 \\
Females & 130.00 & 118.00 & 137.00 \\
& 33.00 & 29.00 & 52.00 \\
& 97.00 & 89.00 & 85.00 \\
\hline \hline
\end{tabular}


$r$ values for QMr, AdvQMr, and RelQMr in both corpora

\begin{tabular}{lrrr}
\hline \hline & 1.00 & 2.00 & \multicolumn{1}{c}{3.00} \\
& Mean & Mean & Mean \\
\hline Males & 17.72 & 23.93 & 9.26 \\
& 6.99 & 7.47 & 4.27 \\
& 10.73 & 16.46 & 5.00 \\
Females & 18.37 & 28.75 & 23.37 \\
& 6.46 & 9.31 & 8.79 \\
& 11.91 & 19.44 & 14.58 \\
\hline
\end{tabular}

$N$ values for QM, AdvQM, and RelQM in Orléans Corpus

\begin{tabular}{lrrr}
\hline \hline & 1.00 & 2.00 & 3.00 \\
& Sum & Sum & Sum \\
\hline Males & 65.00 & 111.00 & 41.00 \\
& 28.00 & 49.00 & 19.00 \\
& 37.00 & 62.00 & 22.00 \\
Females & 95.00 & 55.00 & 110.00 \\
& 21.00 & 9.00 & 43.00 \\
& 74.00 & 46.00 & 67.00 \\
\hline \hline
\end{tabular}

$r$ values for QMr, AdvQMr, and RelQMr in Orléans Corpus

\begin{tabular}{lrrr}
\hline \hline & 1.00 & 2.00 & 3.00 \\
& Mean & Mean & Mean \\
\hline Males & 13.94 & 18.54 & 7.21 \\
& 5.69 & 8.11 & 3.34 \\
& 8.25 & 10.42 & 3.86 \\
Females & 14.36 & 13.25 & 18.99 \\
& 3.23 & 2.18 & 8.39 \\
& 11.13 & 11.07 & 10.60 \\
\hline \hline
\end{tabular}

$N$ values for QM, AdvQM, and RelQM in Bristol Corpus

\begin{tabular}{lrrr}
\hline \hline & 1.00 & 2.00 & 3.00 \\
& Sum & Sum & Sum \\
\hline Males & 51.00 & 30.00 & 8.00 \\
& 16.00 & 7.00 & 4.00 \\
& 35.00 & 23.00 & 4.00 \\
Females & 35.00 & 63.00 & 27.00 \\
& 12.00 & 20.00 & 9.00 \\
& 23.00 & 43.00 & 18.00 \\
\hline
\end{tabular}


$r$ values for QMr, AdvQMr, and RelQMr in Bristol Corpus

\begin{tabular}{lrrr}
\hline \hline & $\begin{array}{c}\text { 1.00 } \\
\text { Mean }\end{array}$ & $\begin{array}{c}2.00 \\
\text { Mean }\end{array}$ & $\begin{array}{c}\text { M.00 } \\
\text { Mean }\end{array}$ \\
\hline Males & 18.66 & 26.63 & 12.00 \\
& 7.31 & 7.15 & 5.50 \\
& 11.35 & 19.48 & 6.51 \\
Females & 19.52 & 36.50 & 26.28 \\
& 7.38 & 12.88 & 9.06 \\
& 12.14 & 23.63 & 17.23 \\
\hline
\end{tabular}

